\title{
Behavior of R.C. Element with Partial Replacement of Copper Slag as a Fine Aggregate on the Properties of Concrete
}

\author{
M. Selvaradjou, R. Baskar,S .SenthilSelvam
}

\begin{abstract}
In recent years, it is a fact that the quantity of good quality natural sand goes on draining. In most of the regions, river sands are abused, which results in severe environmental problems, river banks stability and the safety of bridges. The excessive transportation cost is the major impact for the river sands to be more expensive. In the total concrete volume, about 65 to $80 \%$ is occupied by the aggregates. These problems can be overcome by using slag instead of sands. Slag is a by-product which is made from metal industries like glass, ash plastics, etc as waste materials. These slags are a fine substitute and coarse aggregate to be cast in the concretes and mortarscompositions. In accordance, for replacing fine aggregate several research works are carried out and that solved by using copper slag. Replacing sand with copper slag of about $40 \%$ is proven by most of research as an efficient aggregate. Our research, industrial by-products are applied in order to increase the $40 \%$ copper slag. This composition will be a fine aggregate in concrete to $50 \%, 60 \%$. In another way by using silica fume or marble dust in 10\%, $20 \%$ and $30 \%$ it will be fine aggregate for the concretes
\end{abstract}

\section{INTRODUCTION}

In the world, apart from water concrete is another widely used material.It's directly or indirectly, the human life aspects are based on the concrete. The main components for preparing conventional concrete which are economically available such as cement, aggregate and water. In the industrial era there several construction materials available, among which concrete is uniquely designed material for the civil engineering project. The concrete composition consists of coarse granular material with cement or binder for filling the gap and water which are bind together with aggregate particles as well as the glues.

In our daily life, concrete is extensively utilized for building structures, architectural structures,bridges/overpasses, dams, highways,foundations, fences,poles, pavements, runways, brick/block walls, parking structures, footings forget and pipes. In which it is vital for infrastructure, as humans need it in huge quantities. In the aspect of animal houses also concrete is the often used building materials. In agriculture is used for building silage storage structures and manures.

In worldwide concrete usage is double that of aluminum, steel, wood, and plastic. The broad using of concrete is only possible by the naturally occurring water. As annually, about ten billion tons of concrete is consuming for

Revised Manuscript Received on 14 August, 2019.

M. Selvaradjou, Research scholar Annamalai University, Chidambaram, Tamil Nadu, India

R. Baskar, Professor Department of civil engineering Annamalai University, Chidambaram, Tamil Nadu, India

S .SenthilSelvam, Professor Department of civil engineering SRM University, Chennai, Tamil Nadu, India construction and other various purposes. This enormous usage level states that in the world next to water the most used material is concrete. The concrete's steadiness or its quality would be affects are influenced by the aggregate content in the concrete. The aggregate component which is used in the concrete is shapeless and varied in grading. As in water and cement, the characteristic properties can't alter rather than the quality.

\section{EXPERIMENTAL WORK}

\subsection{Materials Used}

\subsubsection{Cement}

For general concrete construction, PPC (Portland Pozzolana Cement) is the well suited Portland cement. This PPC is on three grade levels such as grade 33, grade 43 and grade 53. These levels are based on strength of the cement at 28 days. According to IS: 4031-1996-part II these grade level test are conducted. At 28 days the strength of the cement is not less than $33 \mathrm{~N} / \mathrm{mm}^{2}, 43 \mathrm{~N} / \mathrm{mm}^{2}$ and $53 \mathrm{~N} / \mathrm{mm}^{2}$ which are graded as grade 33 , grade 43 and grade 53 cements. For our research examination, we use Chettinad Cement of 53-grade cement which meets the requirement as per IS 12269-1987.

\subsubsection{Fine Aggregate}

To retain the composition of fine aggregate same quarry sand is used. According to the Indian Standard Code, IS: 2386 - 1963 water absorption, specific gravity, sieve analysis, moisture content, and bulk density are determined. For the entire experiment, the sand stockpile kept exclusively in the laboratory. As per the IS: 2386 - 1963 (part I) the fine aggregatesgrading's are determined as Grading Zones I, II, III and IV.

\subsubsection{Coarse Aggregate}

About $12.5 \mathrm{~mm}$ of crushed stone aggregates are collected and kept in the laboratory.According to code IS: 2386 1963 (part I), the physical properties are stated.

\subsubsection{Copper Slag}

Copper slag, which is taken for this research is obtained from Sterlite Industries Limited (SIL), Tuticorin, Tamilnadu, Indian.Table 4.3 represents the copper slag's physical properties and sieve chemical properties.

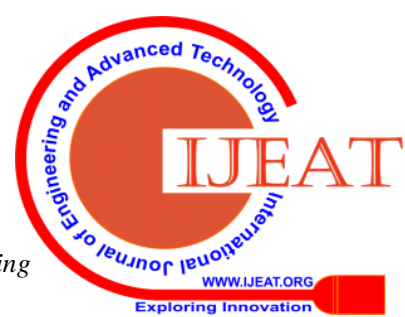




\subsubsection{Additives}

\subsubsection{Silica Fume}

For this research work the Silica fumes are taken from silicon industries, India. The Silica fumes chemical composition are listed on the below table;

\begin{tabular}{|l|l|}
\hline Chemical Composition & Silica Fume \\
\hline Silica di oxide $\left(\mathrm{SiO}_{2}\right)$ & 93.5 \\
\hline Aluminum oxide $\left(\mathrm{Al}_{2} \mathrm{O}_{3}\right)$ & 0.06 \\
\hline Ferric Oxide $\left(\mathrm{Fe}_{2} \mathrm{O}_{3}\right)$ & 0.45 \\
\hline Calcium oxide $(\mathrm{CaO})$ & 0.5 \\
\hline Magnesium Oxide $(\mathrm{MgO})$ & 0.67 \\
\hline Sulphur trioxide $\left(\mathrm{SO}_{2}\right)$ & 0.10 \\
\hline Sodium Oxide $\left(\mathrm{Na}_{2} \mathrm{O}\right)$ & 0.32 \\
\hline Potassium Oxide $\left(\mathrm{K}_{2} \mathrm{O}\right)$ & 0.85 \\
\hline Loss on igniting $(\mathrm{LOI})$ & 2.26 \\
\hline
\end{tabular}

Table 2:1 Silica fume chemical composition

\subsubsection{Marble Dust}

In this work, marble dust is used for the experiment which is collected from Marble manufacturing industries, India. The chemical components of marble dust as below

\begin{tabular}{|c|c|c} 
S.No. & Materials & Marble Powder (\%) \\
\hline 1. & Loss of Ignition (L.O.I) & 43.63 \\
\hline 2. & $\mathrm{CaO}$ & 43.20 \\
\hline 3. & $\mathrm{Fe} 2 \mathrm{O} 3$ & 1.90 \\
\hline 4. & $\mathrm{Al} 2 \mathrm{O} 3$ & 2.50 \\
\hline 5. & $\mathrm{SiO} 2$ & 13.8 \\
\hline 6. & $\mathrm{MgO}$ & 2.70 \\
\hline 7. & $\mathrm{SO} 3$ & 0.07 \\
\hline 8. & $\mathrm{~K} 2 \mathrm{O}$ & 0.60 \\
\hline 9. & $\mathrm{Na} 2 \mathrm{O}$ & 0.90 \\
\hline 10. & $\mathrm{CL}$ & 0.03 \\
\hline
\end{tabular}

Source: Omar M.O. et al (2012)

Table 2.2: Marble dustchemical compositions

\subsubsection{Superplasticizer (Tec Mix 550)}

For floor, wall or foundation the efficient super plasticizer with water reduction properties is vital for the concrete mixture. It increases the workability and minimizes the permeability without changing the cement content. It is well applicable for congested reinforcement and it is fair according to IS 9103-1999.

\subsubsection{Curing}

After demoulding the specimens are cured under the ambient (atmosphere 25 to 35 degree) curing, with a period of 7,14 and 28 days maintained. The process of curingwillbe done effectively under natural calamity.

\section{MIX DESIGN}

In this study, mix design is $\mathrm{m} 25$ grade and the cement ratio is 0.45 . In this experiment totally 30 cubes are taken with standard size of $150 \times 150 \times 150 \mathrm{~mm}$ each. Along with 30 cylinders at a standard diameter $150 \mathrm{~mm}$ height 300, 30 prisms of size $500 \times 100 \times 100 \mathrm{~mm}$. For about 28 days this mixture is cast and cured and tested according to 516-1959 standard.

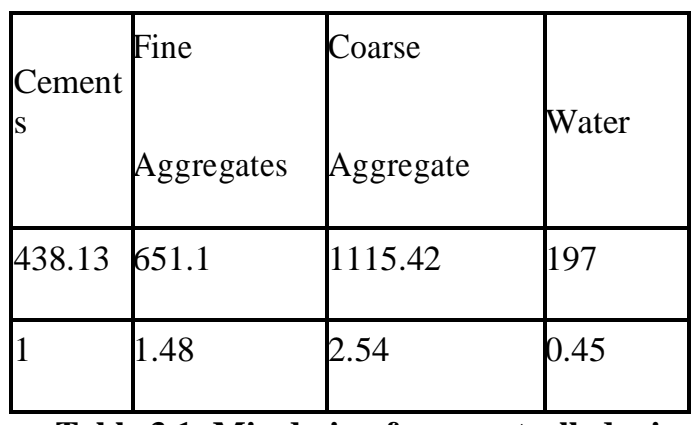

Table 3.1: Mix design for a controlled mix

\section{PREPARATION AND CASTING OF SPECIMEN}

For stating the modulus of elasticity and compressive strength of the concrete's, concrete specimen is prepared. The specimen is prepared by cylindrical molds with size 100X300mm, Cubical molds of size $150 \times 150 \mathrm{~mm}$ and prism size of $100 \times 100 \times 500 \mathrm{~mm}$ are taken. As per the Indian Standard Specifications IS: 516-1959 [4] these specimens are prepared. Molds are well cleaned and oiled. Before casting these are well tightened according to the correct dimensions. In order to prevent leakage from the slurry, there are no gaps in the specimen. Initially, for about 1 minutesthe mixing with coarse and fine aggregates is done. Next another 1 minute the cement is added and mixed, lastly, water slowly added. For testing the modulus of elasticity, compressive strength and flexural strength fresh concrete with the molds $100 \times 100 \times 500 \mathrm{~mm}$, $150 \times 150 \times 150 \mathrm{~mm}$ and $150 \times 300 \mathrm{~mm}$ are casted respectively. For two-layer molds, specimens are taken for casting, by which each layer get merged using a vibrating table. These specimens casting should be done as per the BIS1881:116[44].

Then these specimens are kept in a steel mold at ambient conditionsfor about first $24 \mathrm{~h}$. Then with care without damaging the edges they are remolded and kept in the curing tank at ambient temperature. In this study, at ambient temperature $27^{\circ} \mathrm{C}$ curing is done and each test result has ordinarily three replicate tests.

\section{TEST RESULT AND DISCUSSION}

\subsection{Compressive Strength Test}

For casting the cubes, in the machine, the specimen is positioned and applying loads to the cubes opposite sides as cast. By keeping the spherically seated plate as a center of thrust, cautiously the specimen axis is aligned.

There should be no packing between the test specimen faces and steel plates testing machine. On the specimen, a spherically seated block is allowed and by hands gently the movable portion to be rotated which results in uniform seating.

The load is applied and continuously increased without shock till the specimenresistance is maximized the load breaks down, further no more load is continued. Then the specimen'smaximum load is recorded.

Published By:

Blue Eyes Intelligence Engineering

\& Sciences Publication 
Table 5.1: Observation of 7 days - compressive strength of Control Concrete

\begin{tabular}{|l|l|l|l|}
\hline $\begin{array}{l}\text { SI. } \\
\text { NO. }\end{array}$ & Cube & $\begin{array}{l}\text { Compressive } \\
\text { strength } \\
\text { (N/mm2) }\end{array}$ & $\begin{array}{l}\text { Average } \\
\text { compressive } \\
\text { Strength } \\
\text { (N/mm2) }\end{array}$ \\
\hline 1 & $150 \times 150 \times 150$ & 18.80 & \multirow{2}{*}{18.80} \\
\hline 2 & $150 \times 150 \times 150$ & 18.65 & \\
\hline 3 & $150 \times 150 \times 150$ & 18.95 & $\mathrm{~N} / \mathrm{mm}^{2}$. \\
\hline
\end{tabular}

Table 5.2: The 14 days of Control Concrete cubes Compressive strength

\begin{tabular}{|l|l|l|l|}
\hline $\begin{array}{l}\text { SI. } \\
\text { NO. }\end{array}$ & Cube & $\begin{array}{l}\text { Compressive } \\
\text { strength } \\
\text { (N/mm2) }\end{array}$ & $\begin{array}{l}\text { Average } \\
\text { compressive } \\
\text { Strength } \\
\text { (N/mm2) }\end{array}$ \\
\hline 1 & $150 \times 150 \times 150$ & 25.20 & \multirow{2}{*}{25.40} \\
\hline 2 & $150 \times 150 \times 150$ & 25.60 & \\
\cline { 1 - 2 } 3 & $150 \times 150 \times 150$ & 25.40 & N/mm ${ }^{2}$
\end{tabular}

Table 5.3: The Control Concrete cubes Compressive strength for 28 days

\begin{tabular}{|l|l|l|l|}
\hline $\begin{array}{l}\text { SI. } \\
\text { NO. }\end{array}$ & Cube & $\begin{array}{l}\text { Compressive } \\
\text { strength } \\
(\mathbf{N} / \mathbf{m m} 2)\end{array}$ & $\begin{array}{l}\text { Average } \\
\text { compressive } \\
\text { Strength } \\
\text { (N/mm2) }\end{array}$ \\
\hline 1 & $150 \times 150 \times 150$ & 31.80 & \multirow{2}{*}{31.70} \\
\hline 2 & $150 \times 150 \times 150$ & 31.72 & \\
\hline 3 & $150 \times 150 \times 150$ & 31.60 & $\mathrm{~N} / \mathrm{mm}^{2}$.
\end{tabular}

The controlled cube's compressive strength of 7days are $18.8 \mathrm{~N} / \mathrm{mm}^{2} 14$ days $=25.48 \mathrm{~N} / \mathrm{mm}^{2}{ }^{2} 28$ days $31.70 \mathrm{~N} / \mathrm{mm}^{2}$

Then the copper slag is used aspartially fine aggregate, then the concrete compressive strength is increased by 49.10 $\%$ with $40 \%+10 \%$ SF. At the same manner, replacement of copper slag is decreased by $14.76 \%$ with $40 \%+10 \%$ MD. The copper slags compressive strength as partial replacement is decreased by $40.37 \%$ with $40 \%+10 \% \mathrm{SF}+$ $10 \%$ MD. The copper slags compressive strength on partial replacement is increased by $1 \%$ with $50 \% \mathrm{CS}+10 \%$ \& 10 $\%$ with $60 \mathrm{CS}+10 \mathrm{SF}$. Then further addition results on decreasing.

Table 5.4 : Concrete cubes Compressive strength

Sand replaced by various \% of COPPER SLAG:

\begin{tabular}{|l|c|c|c|c|}
\hline S.NO & $\begin{array}{c}\text { \% of } \\
\text { Copper } \\
\text { Slag }\end{array}$ & $\begin{array}{l}\mathbf{7} \text { days } \\
\mathbf{N} / \mathbf{m m}^{2}\end{array}$ & $\begin{array}{l}\mathbf{1 4} \text { days } \\
\mathbf{N} / \mathbf{m m}^{2}\end{array}$ & $\begin{array}{l}\mathbf{2 8} \text { days } \\
\mathbf{N} / \mathbf{m m}^{2}\end{array}$ \\
\hline 1 & CS 20 & 26.50 & 32.30 & 39.00 \\
\hline 2 & CS 40 & 29.40 & 35.80 & 42.60 \\
\hline 3 & CS 60 & 23.20 & 30.30 & 34.70 \\
\hline 4 & CS 80 & 22.10 & 28.30 & 30.40 \\
\hline 5 & CS 100 & 18.60 & 22.10 & 25.20 \\
\hline
\end{tabular}

From this table, 7, 14, 28 days strength of CS $\mathbf{4 0 \%}$ is increased.
Table 5.5 : Concrete cubes Compressive strength Introducing various $\%$ of ADDITIVES (silica fume $\&$ marble dust) with $40 \%$ copper slag in concrete

\begin{tabular}{|c|c|c|c|c|}
\hline $\begin{array}{l}\text { Si. } \\
\text { No. }\end{array}$ & Specimen & $\begin{array}{l}7 \text { DAYS } \\
\left(\mathrm{N} / \mathrm{mm}^{2}\right)\end{array}$ & $\begin{array}{l}14 \\
\text { DAYS } \\
(\mathrm{N} / \mathrm{mm} 2)\end{array}$ & $\begin{array}{l}28 \\
\text { DAYS } \\
(\mathrm{N} / \mathrm{mm} 2)\end{array}$ \\
\hline 1. & Control mix & 18.80 & 25.40 & 31.70 \\
\hline 2. & $\mathrm{CS} 40 \%$ & 29.40 & 35.80 & 42.60 \\
\hline 3. & $\begin{array}{l}40 \% \mathrm{CS}+ \\
10 \% \mathrm{SF}\end{array}$ & 30.72 & 40.17 & 47.26 \\
\hline 4. & $\begin{array}{l}40 \% \text { CS + } \\
20 \% \mathrm{SF}\end{array}$ & 18.86 & 24.67 & 29.02 \\
\hline 5. & $\begin{array}{l}40 \% \text { CS + } \\
30 \% \mathrm{SF}\end{array}$ & 16.34 & 21.37 & 25.14 \\
\hline 6. & $\begin{array}{l}40 \% \text { CS }+ \\
10 \% \mathrm{MD}\end{array}$ & 17.24 & 24.57 & 27.02 \\
\hline 7 & $\begin{array}{l}40 \% \text { CS }+ \\
20 \% \mathrm{MD}\end{array}$ & 17.48 & 22.89 & 26.90 \\
\hline 8 & $\begin{array}{l}40 \% \mathrm{CS}+ \\
30 \% \mathrm{MD}\end{array}$ & 14.65 & 19.16 & 22.54 \\
\hline 9. & $\begin{array}{lr}40 \% & \mathrm{CS}+ \\
10 \% & \mathrm{MD}+ \\
10 \% & \mathrm{SF}\end{array}$ & 15.34 & 16.08 & 18.90 \\
\hline
\end{tabular}

From this table, 7, 14, 28 days strength of $\mathbf{C S ~} \mathbf{4 0 \%}+\mathbf{S F}$ $10 \%$ is increased.

Table 5.6: Concrete cubes Compressive strength Replacement of Sand by various \% of COPPER SLAG with $10 \%$ SILICA FUME:

\begin{tabular}{|l|l|l|l|l|}
\hline $\begin{array}{l}\text { Si. } \\
\text { No. }\end{array}$ & Specimen & $\begin{array}{l}\text { 7 DAYS } \\
\text { (N/mm2) }\end{array}$ & $\begin{array}{l}\text { 14 DAYS } \\
\text { (N/mm2) }\end{array}$ & $\begin{array}{l}\text { 28 DAYS } \\
\text { (N/mm2) }\end{array}$ \\
\hline 1. & $\begin{array}{l}\text { CS 50\% + } \\
10 \% \text { SF }\end{array}$ & 18.73 & 25.46 & 31.83 \\
\hline 2. & $\begin{array}{l}\text { CS 60\%+ } \\
10 \% \text { SF }\end{array}$ & 19.97 & 27.84 & 34.80 \\
\hline 3. & $\begin{array}{l}\text { CS 70\%+ } \\
10 \% \text { SF }\end{array}$ & 23.41 & 25.41 & 31.76 \\
\hline
\end{tabular}

From this table, 7, 14, 28 days strength of SF $10+\mathrm{CS}$ $50 \%, 60 \%, 70 \%$ was decreased with comparing CS $40 \%+$ $\mathrm{SF} 10 \%$ and CS $40 \%$.

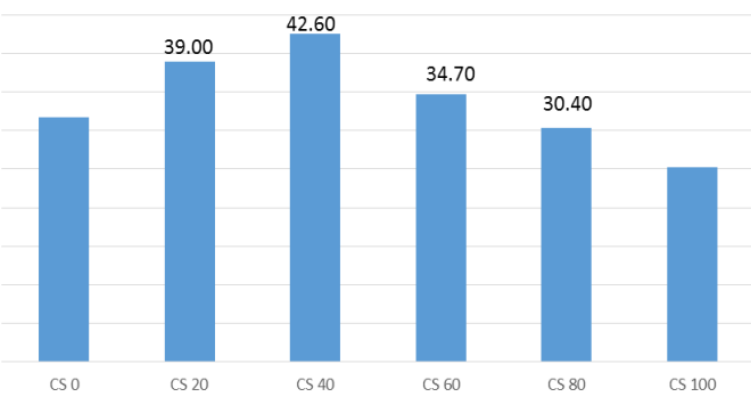

Fig. 5.1 Compressive strength of various \% of CS 


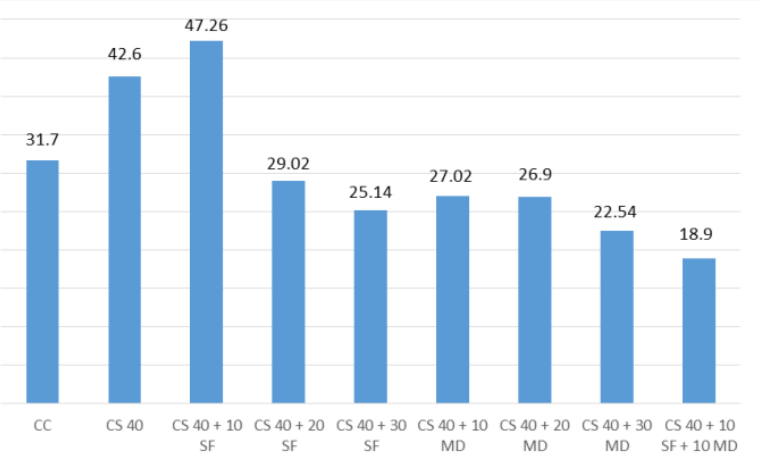

Fig. 5.2 Compressive strength of $40 \%$ of CS with various \% of Additives

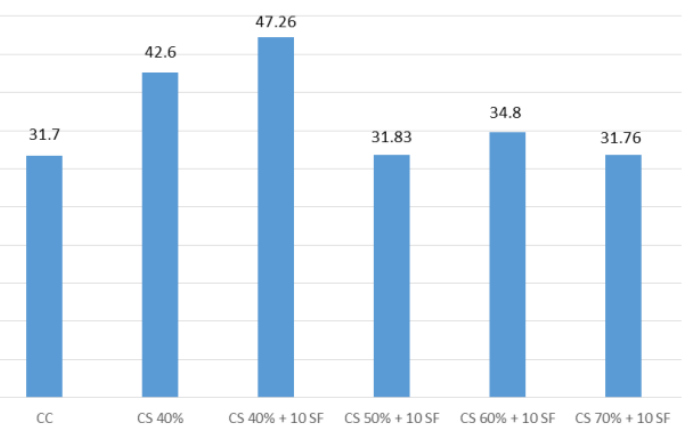

Fig. 5.3 Compressive strength of increased \% of CS with $10 \%$ of Additives (SF)

\section{FLEXURAL STRENGTH}

In order to evaluate the flexural strength (ASTM C78-94), the three prisms are taken and tested at under third point loading conditions. The average of flexural strength is represented as below;

$\mathrm{Fcr}=\mathrm{PL} / \mathrm{bd}^{2}$

Where,

Fcr is the flexural strength;

b determines average specimenwidth, and

d determines average specimen depth

On this observation copper slag is applied, the flexural strength of concrete is maximized and the test is carried for three times. On which $30.57 \%$ with $40 \%, 37.43 \%$ with $40 \%$ $+10 \% \mathrm{SF}$ and $4 \%$ with $40 \%+10 \% \mathrm{MD}$. Next, the replacing fine aggregate with copper slag is decreased by $12.86 \%$ with $40 \%+10 \mathrm{CS}+10 \%$ MD. On partial replacement with copper slag, the concrete's flexural strength increased by $12.86 \%$ with $50 \%+10 \%$ SF \& $18 \%$ with $60 \% \mathrm{CS}+10 \%$ $\mathrm{SF}$.

Table 6.1: The Concrete test result of Flexural strength

Sand replaced by various \% of COPPER SLAG:

\begin{tabular}{|l|l|l|}
\hline S.NO & $\begin{array}{l}\text { MIX } \\
\text { PROPORTION }\end{array}$ & $\begin{array}{l}\text { FLEXURAL } \\
\text { STRENGTH } \\
\text { N/mm }\end{array}$ \\
\hline 1. & CS 0 & 3.50 \\
\hline 2. & CS 20 & 3.65 \\
\hline 3. & CS 40 & 3.72 \\
\hline 4. & CS 60 & 3.58 \\
\hline 5. & CS 80 & 3.61 \\
\hline 6. & CS 100 & 3.66 \\
\hline
\end{tabular}

From this table, the Flexural strength for 28 days of CS $\mathbf{4 0 \%}$ is maximized
Table 6.2: Concrete flexural strength test result

Introducing various \% of ADDITIVES (silica fume \& marble dust) with $40 \%$ copper slag in concrete

\begin{tabular}{|c|c|c|c|c|}
\hline S.NO. & SPECIMEN & $\begin{array}{l}7 \text { DAYS } \\
\text { N/mm2 }\end{array}$ & $\begin{array}{l}14 \\
\text { DAYS } \\
\text { N/mm }\end{array}$ & $\begin{array}{l}28 \\
\text { DAYS } \\
\text { N/mm }\end{array}$ \\
\hline 1. & Control mix & 2.80 & 3.15 & 3.50 \\
\hline 2. & CS $40 \%$ & 3.78 & 4.19 & 4.57 \\
\hline 3. & $\begin{array}{l}40 \% \mathrm{CS}+10 \% \\
\mathrm{SF}\end{array}$ & 3.88 & 4.44 & 4.81 \\
\hline 4. & $\begin{array}{l}40 \% \mathrm{CS}+20 \% \\
\mathrm{SF}\end{array}$ & 3.04 & 3.48 & 3.77 \\
\hline 5. & $\begin{array}{l}40 \% \mathrm{CS}+30 \% \\
\mathrm{SF}\end{array}$ & 2.83 & 3.24 & 3.51 \\
\hline 6. & $\begin{array}{l}40 \% \mathrm{CS}+10 \% \\
\mathrm{MD}\end{array}$ & 2.91 & 3.46 & 3.64 \\
\hline 7. & $\begin{array}{l}40 \% \mathrm{CS}+20 \% \\
\mathrm{MD}\end{array}$ & 2.93 & 3.56 & 3.63 \\
\hline 8. & $\begin{array}{l}40 \% \mathrm{CS}+30 \% \\
\mathrm{MD}\end{array}$ & 2.70 & 3.31 & 3.23 \\
\hline 9. & $\begin{array}{l}40 \% \mathrm{CS}+10 \% \\
\mathrm{MD}+10 \% \mathrm{SF}\end{array}$ & 2.71 & 2.81 & 3.05 \\
\hline
\end{tabular}

From this table, 28 days Flexural strength of CS $\mathbf{4 0 \% +}$ SF $10 \%$ is increased.

Table 6.3Test result for flexural strength of concrete Sand replaced by various \% of COPPER SLAG with 10\% SILICA FUME:

\begin{tabular}{|l|l|l|l|l|}
\hline S.NO. & SPECIMEN & $\begin{array}{l}\mathbf{7} \\
\text { DAYS } \\
\text { N/mm2 }\end{array}$ & $\begin{array}{l}\mathbf{1 4} \\
\text { DAYS } \\
\text { N/mm }\end{array}$ & $\begin{array}{l}\mathbf{2 8} \\
\text { DAYS } \\
\text { N/mm }\end{array}$ \\
\hline 1. & $\begin{array}{l}\text { CS 50\% + } \\
10 \% \text { SF }\end{array}$ & 2.96 & 3.53 & 3.95 \\
\hline 2. & $\begin{array}{l}\text { CS 60\%+ 10\% } \\
\text { SF }\end{array}$ & 3.13 & 3.69 & 4.13 \\
\hline 3. & $\begin{array}{l}\text { CS 70\%+ 10\% } \\
\text { SF }\end{array}$ & 3.39 & 3.53 & 3.94 \\
\hline
\end{tabular}

From this table, 28 days Flexural strength of CS 50\%, $\mathbf{6 0 \%}, \mathbf{7 0} \%$ + SF $10 \%$ is decreased with comparing CS $40 \%$ $+\mathrm{SF} 10 \%$ and CS $40 \%$.

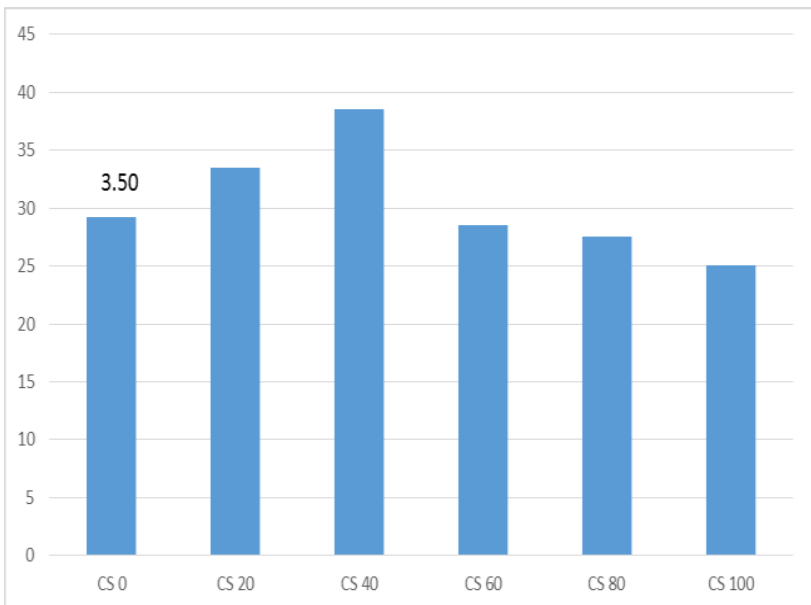

Fig. 6.1 Flexural strength of various \% of CS 


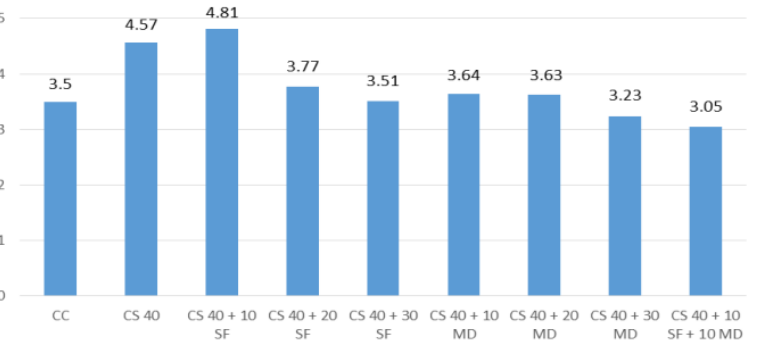

Fig. 6.2 Flexural strength of $40 \%$ of $\mathrm{CS}$ with various $\%$ of Additives

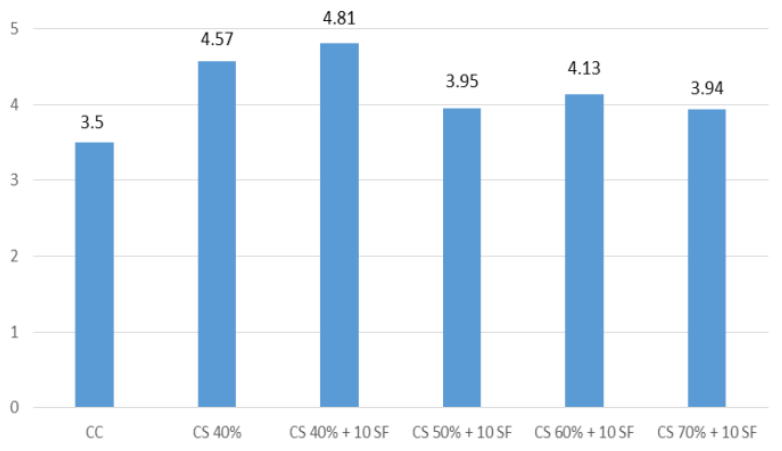

Fig. 6.3 Flexural strength of increased \% of CS with $10 \%$ of Additives (SF)

\section{MODULUS OF ELASTICITY}

The test result represents, on replacing with copper slag results in minimization on modulus of elasticity. The control concrete's modulus of Elasticity is $31.70 \mathrm{~N} / \mathrm{mm} 2$. On replacing with copper slag $20 \%$ of modulus of elasticity is increased by $14.55 \%$ and $40 \%$ is increased by $32 \%$ respectively. On comparison to control concrete, the replacement results modulus of elasticity for $60 \%, 80 \%$, and $100 \%$ is minimized by $2 \%, 5 \%$ and $14 \%$. The 28 days of modulus of Elasticity is represented at the graph2.

Modulus of Elasticity of Concrete represents from stress of zero the slope ofa line drawn to a compressive stress of $0.45 f^{\prime}$ 'c.It is shown that on applying the stress the concrete resistance is being deformed. The concrete strength is reliant on aggregates relative proportion and modulus of elasticity. Modulus of Elasticity specimens are measured the empirical formula given by IS: 456-2000, that is formula $E=5000$ $\sqrt{\text { fck. }}$.

Where cube compressive strength for 28 days is fck

Table 3 states the Elasticity of concrete test results

Table7.1: Test result for modulus of elasticity

Sand replaced by various \% of COPPER SLAG:

\begin{tabular}{|l|c|c|}
\hline S.NO & $\begin{array}{c}\text { MIX } \\
\text { PROPORTION }\end{array}$ & $\begin{array}{c}\text { EC } \\
\mathbf{N} / \mathbf{m m}^{\mathbf{2}}\end{array}$ \\
\hline 1. & CS 0 & 29.20 \\
\hline 2. & CS 20 & 33.45 \\
\hline 3. & CS 40 & 38.60 \\
\hline 4. & CS 60 & 28.50 \\
\hline 5. & CS 80 & 27.50 \\
\hline 6. & CS 100 & 25.10 \\
\hline
\end{tabular}

From this table, 28 days modulus of elasticity of CS $\mathbf{4 0 \%}$ is increased
Table 7.2 Test result for modulus of elasticity

Introducing various \% of ADDITIVES (silica fume $\&$ marble dust) with $40 \%$ copper slag in concrete

\begin{tabular}{|c|c|c|c|c|}
\hline S.NO & SPECIMEN & $\begin{array}{l}7 \text { DAYS } \\
\text { N/mm² }\end{array}$ & $\begin{array}{l}14 \\
\text { DAYS } \\
\text { N/mm² }\end{array}$ & $\begin{array}{l}28 \\
\text { DAYS } \\
\text { N/mm }{ }^{2} \\
\end{array}$ \\
\hline 1. & Control mix & 18.98 & 24.82 & 29.20 \\
\hline 2. & CS $40 \%$ & 25.09 & 32.81 & 38.60 \\
\hline 3. & $\begin{array}{l}40 \% \mathrm{CS}+10 \% \\
\mathrm{SF}\end{array}$ & 26.60 & 33.30 & 39.00 \\
\hline 4. & $\begin{array}{l}40 \% \mathrm{CS}+20 \% \\
\mathrm{SF}\end{array}$ & 16.01 & 22.17 & 24.64 \\
\hline 5. & $\begin{array}{l}40 \% \mathrm{CS}+30 \% \\
\mathrm{SF}\end{array}$ & 14.51 & 18.03 & 20.73 \\
\hline 6. & $\begin{array}{l}40 \% \mathrm{CS}+10 \% \\
\mathrm{MD}\end{array}$ & 16.40 & 22.53 & 24.49 \\
\hline 7. & $\begin{array}{l}40 \% \mathrm{CS}+20 \% \\
\mathrm{MD}\end{array}$ & 16.25 & 21.51 & 23.49 \\
\hline 8. & $\begin{array}{l}40 \% \mathrm{CS}+30 \% \\
\mathrm{MD}\end{array}$ & 14.98 & 17.98 & 19.98 \\
\hline 9. & $\begin{array}{l}40 \% \mathrm{CS}+10 \% \\
\mathrm{MD}+10 \% \mathrm{SF}\end{array}$ & 11.92 & 14.00 & 18.38 \\
\hline
\end{tabular}

From this table, 28 days modulus of elasticity of CS $\mathbf{4 0 \%}$ + SF $10 \%$ is increased.

Table 7.3 Test result for modulus of elasticity Sand replaced by various \% of COPPER SLAG with 10\% SILICA FUME:

\begin{tabular}{|l|l|l|l|l|}
\hline S.NO. & SPECIMEN & $\begin{array}{l}\text { 7 DAYS } \\
\text { N/mm }\end{array}$ & $\begin{array}{l}\mathbf{1 4} \\
\text { DAYS } \\
\text { N/mm }\end{array}$ & $\begin{array}{l}\mathbf{2 8} \\
\text { DAYS } \\
\text { N/mm }\end{array}$ \\
\hline 1. & $\begin{array}{l}\text { CS } 50 \%+10 \% \\
\text { SF }\end{array}$ & 17.91 & 23.45 & 29.32 \\
\hline 2. & $\begin{array}{l}\text { CS 60\%+ 10\% } \\
\text { SF }\end{array}$ & 17.23 & 23.84 & 29.80 \\
\hline 3. & $\begin{array}{l}\text { CS 70\%+ 10\% } \\
\text { SF }\end{array}$ & 18.81 & 23.14 & 28.93 \\
\hline
\end{tabular}

From this table, 28 days modulus of elasticity of CS $\mathbf{5 0 \%}, \mathbf{6 0 \%}, \mathbf{7 0 \%}+\mathbf{S F} \mathbf{1 0 \%}$ is decreased with comparing CS $40 \%+$ SF $10 \%$ and CS $40 \%$

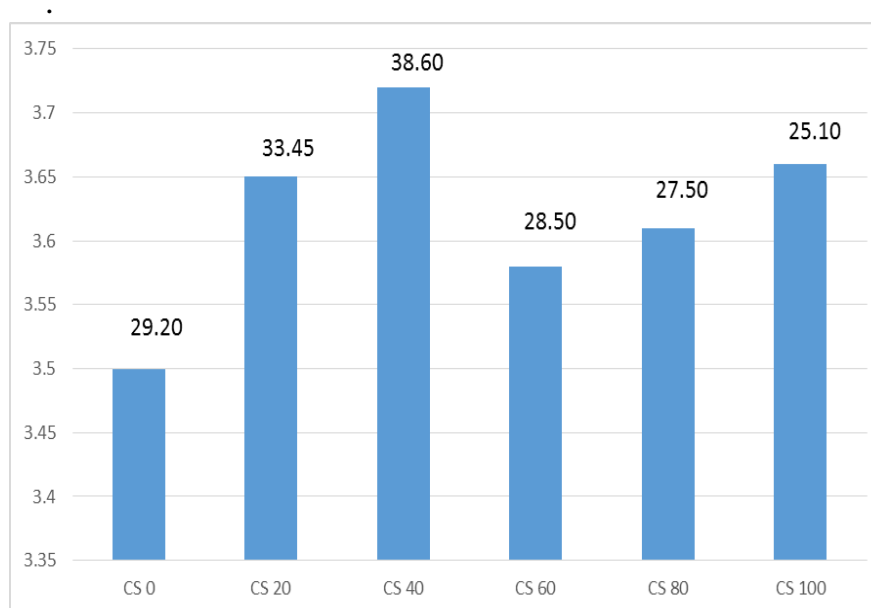

Fig. 7.1 Modulus of elasticity for various \% of CS 

AGGREGATE ON THE PROPERTIES OF CONCRETE

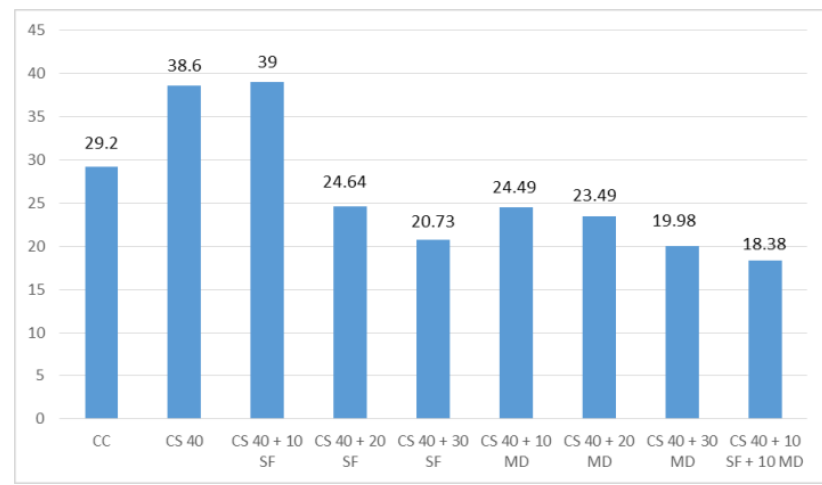

Fig. 7.2 Modulus of elasticity for $40 \%$ of CS with various \% of Additives

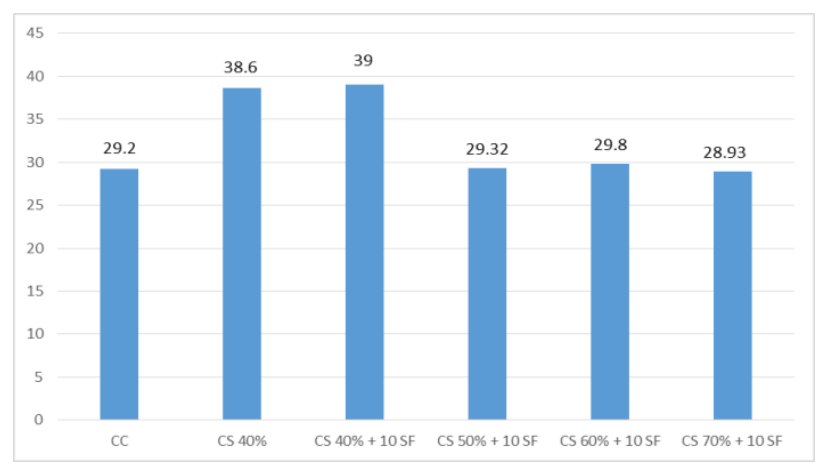

Fig. 7.3 Modulus of elasticity for increased \% of CS with $10 \%$ of Additives (SF)

\section{CONCLUSION}

By means of partially replacing copper slag, the compressive strength of concrete's $34.38 \%$ is maximized to $40 \%$.

By means of partially replacing copper slag, the compressive strength of concrete's is maximized to $49.10 \%$ with $40 \%+10 \% \mathrm{SF}$

By means of partially replacing copper slag, the compressive strength of concrete's is minimized to $14.76 \%$ with $40 \%+10 \% \mathrm{MD}$

By means of partially replacing copper slag, the compressive strength of concrete's is minimized to $40.37 \%$ with $40 \%+10 \% \mathrm{SF}+10 \% \mathrm{MD}$

By means of partially replacing copper slag, the compressive strength of concrete's is maximized by $1 \%$ with $50 \% \mathrm{CS}+10 \%$ \& $10 \%$ with $60 \mathrm{CS}+10$ SF further addition goes on minimized

By replacing with copper slag, Flexural strength of concrete's about $30.57 \%$ is maximized to $40 \%$

By replacing with copper slag, Flexural strength of concrete's about $37.43 \%$ is maximized to $40 \%+10 \% \mathrm{SF}$

By replacing with copper slag, Flexural strength of concrete's about $4 \%$ is maximized to $40 \%+10 \% \mathrm{MD}$

By replacing with copper slag, Flexural strength of concrete's about $12.86 \%$ is minimized with $40 \%+10 \mathrm{CS}$ $+10 \% \mathrm{MD}$

By replacing with copper slag, Modulus of elasticity of concrete's with $32.19 \%$ is maximized to $40 \%$

By replacing with copper slag, Modulus of elasticity of concrete's with $33.56 \%$ is maximized with $40 \%+10 \%$ SF

By replacing with copper slag, Modulus of elasticity of concrete's with $33.56 \%$ is maximized with $40 \%+10 \% \mathrm{MD}$
By replacing with copper slag, Modulus of elasticity of concrete's is minimized to $16.13 \%$ with $40 \%+10 \mathrm{CS}+10 \%$ MD

By replacing with copper slag, Modulus of elasticity of concrete's is minimized to $0.5 \%$ with $50 \%+10 \%$ SF \&2.05 $\%$ with $60 \% \mathrm{CS}+10 \% \mathrm{SF}$

\section{REFERENCES}

1. PicotrDybel, kazimierzFurtak (2017). Influence of silica fume content on the quality of bond conditions in high-perform concrete specimens. Archives of Civil and Mechanical Engg., 17(2017)795-805.

2. S.Chithra, S.R.R.Senthilkumar, K.chinnaraju (2016). The effect of colloidal nano-silica on workability, mechanical and durability properties of high-performance concrete with copper slag as partial fine aggregate. Construction and building materials113(2016) 794 804

3. M.Mazloom, A.A.RamezanianpourJ.J.Brooks(2004). Effect of silica fume on mechanical properties of high-strength concrete. Cement \& concrete composites 26 (2004) 347-357

4. Mohammad Iqbal Khan, Rafat Siddique (2011). Utilization of silica fume in concrete: Review of durability properties. Resources, Conservation, and Recycling 57(2011) 30-35

5. R.Rodrigues, J.de Brito, M.Sardinha (2015). Mechanical properties of structural concrete containing very fine aggregates from marble cutting sludge. Construction and building Materials 77(2015) 349356.

6. Manuel Sardinha, Jorge de Brito, Ricardo Rodigues(2016). Durability properties of structural concrete containing very fine aggregates of marble sludge. Construction and building Materials 119(2016) 45-52.

7. Mohammad Iqbal Khan, Rafat Siddique (2011). Utilization of silica fume in concrete: Review of durability properties. Resources, Conservation and Recycling 57(2011).

8. R.Rodrigues, J.de Brito, M.Sardinha (2015). Mechanical properties of structural concrete containing very fine aggregates from marble cutting sludge. Construction and building Materials 77(2015) 349356.

9. Manuel Sardinha, Jorge de Brito, Ricardo Rodigues(2016). Durability properties of structural concrete containing very fine aggregates of marble sludge. Construction and building Materials 119(2016) 45-52.

10. Gulden CaginUlubeyli, TurhanBilir, RecepArtir(2016). Durability properties of concrete produced by marble waste as aggregate or mineral additives. Procedia Engineering 161 (2016) 543-548

11. Gulden CaginUlubeyli, RecepArtir (2015). Properties of hardened concrete produced by waste marble powder. Procedia Engineering 195 (2015) 2181-2190

12. M.Najimi, J.Sobhani, A.R.Pourkhorshidi(2011). The durability of copper slag contained concrete exposed to sulfate attack. Construction and building Materials 25(2011) 1895-1905

13. Khalifa S.al-Jabri, Makoto Hisada, Salem K.Al-Oraimi, Abdullah H.Al-Saidy (2009). Copper slag as sand replacement for highperformance concrete. Cement \& Concrete Composites 31 (2009) 483-488

14. Mostafa Khanzadi, Ali Behnood (2009). Mechanical properties of high-strength concrete incorporating copper slag as coarse aggregate Construction and building Materials 23(2009) 2183-2188

15. P.S. Ambily, C.Umarani, K. Rvisankar, PrabhatRanjanPrem, B.H Bharatkumar, Nagesh R. Iyer (2015). Studies on Ultra-high performance concrete incorporating copper slag as fine aggregate. Construction and building Materials 77 (2015) 233-240. 